\title{
Establishment and characterization of a receptor- negative, hormone-nonresponsive breast cancer cell line from an Iraqi patient
}

This article was published in the following Dove Press journal:

Breast Cancer: Targets and Therapy

7 August 2015

Number of times this article has been viewed

\author{
Ahmed Majeed \\ Al-Shammari' \\ Mortadha A Alshami² \\ Mahfoodha Abbas Umran² \\ Asmaa Amer Almukhtar ${ }^{3}$ \\ Nahi Y Yaseen' \\ Khansaa Raad' \\ Ayman A Hussien' \\ 'Experimental Therapy Department, \\ Iraqi Center for Cancer and Medical \\ Genetic Research, Mustansiriya \\ University, ${ }^{2}$ Biotechnology \\ Department, Collage of Science, \\ Baghdad University, ${ }^{3}$ Medical Genetics \\ Department, Iraqi Center for Cancer \\ and Medical Genetic Research, \\ Mustansiriya University, Baghdad, Iraq
}

Correspondence: Ahmed Majeed Al-Shammari

Experimental Therapy Department, Iraqi Center for Cancer and Medical Genetic Research, Mustansiriya University, Box 15007, Al-Yarmook Post

Office, Baghdad, Iraq

Tel +9647809/4 3825

Email ahmed.alshammari@iccmgr.org

\begin{abstract}
A new breast cancer cell line (AMJ13) has been established from an Iraqi breast cancer patient. It is considered unique because it is the first for an Iraqi population, and is expected to be a useful tool in breast cancer research. The AMJ13 cell line was established from the primary tumor of a 70-year-old Iraqi woman with a histological diagnosis of infiltrating ductal carcinoma. The cells were morphologically characterized by light and scanning electron microscopy, and found to be elongated multipolar epithelial-like cells with a population doubling time of 22 hours. The anchorage-independent growth ability test showed that the cells were able to grow in semisolid agarose, confirming their transformed nature. Cytogenetic study of these cells showed chromosomal aberrations with many structural and numerical abnormalities, producing chromosomes of unknown origin called marker chromosomes. Immunocytochemistry showed that the estrogen receptor and the progesterone receptor were not expressed, and a weak positive result was found for HER2/neu gene expression. AMJ13 cells were positive for BRCA1 and BRCA2, as well as for vimentin. This cell line should be useful when testing new therapies for breast cancer in the Middle East.
\end{abstract}

Keywords: ductal carcinoma, marker chromosomes, estrogen receptor, progesterone receptor

\section{Introduction}

Breast cancer is the most common malignancy in women worldwide. ${ }^{1}$ In Iraq, breast cancer accounts for about one-third of the cancers affecting women (32\%) according to the Iraqi Cancer Registry, which also shows that breast cancer ranks first among the cancers affecting the Iraqi population. ${ }^{2}$ In general, cell lines are an important tool in cancer research, their major benefit being that they provide an unlimited supply of a relatively homogeneous cell population capable of self-replication that can be widely distributed to facilitate comparative studies. ${ }^{3}$ Human cancer cell line cultures are considered to be a model of physiological functioning in vivo; so these enable research on cancer cell biology and are useful for developing new strategies to prevent cancer cell growth and progression of the disease. ${ }^{4}$ Important biomarkers that have been analyzed in detail in patients with breast cancer are the hormone receptors, including the estrogen receptor (ER) and progesterone receptor (PR), and the Her-neu2 gene. ${ }^{4}$ Using these three parameters for molecular classification, breast cancers can be classified into five types that provide important information with regard to treatment. ${ }^{5}$

Cells in culture can also be characterized for chromosomal aberrations, which are detected mainly by conventional cytogenetics. ${ }^{6}$ Cytogenetic studies of mammary adenocarcinoma cell lines are essential for understanding the pathogenesis of 
these cancers. ${ }^{7,8}$ The implications of these chromosomal alterations has opened up a new and promising route toward better understanding of breast cancer. ${ }^{9}$ The chromosomal alterations in such cancers are often numerous, and marker chromosomes often demonstrate hyperploidy. ${ }^{10}$ The aim of this work was to establish a cell model to better characterize and understand breast cancer in Iraqi women and to develop more effective therapies for the disease.

\section{Materials and methods Clinical history}

The patient from whom this cell line derived was a 70-yearold female who lived in the city of Al-Ameen in Baghdad. She was $160 \mathrm{~cm}$ in height, weighed $70 \mathrm{~kg}$, and had had six children. She had undergone a right-sided mastectomy for breast cancer, but had no genetic or chronic diseases. The histological sample of her breast mass that was used to established our cell line showed poorly differentiated infiltrative ductal carcinoma (Figure $1 \mathrm{~A}$ and B), which was graded 3/3 according to the Nottingham modification of the Bloom-Richardson system, with no vascular invasion seen. The nipple and resection margins were free of malignancy. All axillary lymph nodes $(n=11)$ were free of malignancy. According to the TNM classification, clinical TNM staging of this patient is T2 N0 Mx. Paraffin sections were positive for the ER and PR and positive for the Her/Neu2 tumor suppressor gene. The study was approved by Iraqi Center for Cancer and Medical, Genetic, and Scientific Institutional Review Board, and had received the patient consent for the use of patient-derived cell line.

\section{Primary tumor processing and cell culture}

The tumor specimen was washed in phosphate-buffered saline (PBS), minced into small pieces (approximately $2 \mathrm{~mm}$ in size), and digested with and without collagenase. The cell suspension was then filtered through sterile mesh to separate the undigested tissue, after which the filtrate was centrifuged at $1,500 \mathrm{rpm}$ for 10 minutes. The pellet obtained was resuspended in Roswell Park Memorial Institute medium supplemented with $20 \%$ fetal bovine serum, $100 \mathrm{IU}$ of penicillin, and $100 \mu \mathrm{g}$ of streptomycin. The suspension was then transferred to a tissue culture flask and incubated at $37^{\circ} \mathrm{C}$. The tumor cells were passaged every 3-4 days, and every few passages were frozen in liquid nitrogen. The serum requirement for further passages was $10 \%$.

\section{Analysis of morphology and morphometry}

The cells were cultured on a Labtek tissue culture chamber slide, then fixed in $4 \%$ formalin for 10 minutes, rinsed gently in PBS, and stained with hematoxylin and eosin for study by light microscopy. For scanning electron microscopy, the cells were cultured on cover slips and fixed after confluency in $4 \%(\mathrm{v} / \mathrm{v})$ glutaraldehyde in $0.1 \mathrm{M}$ PBS buffer $(\mathrm{pH} 7.4)$ for 4 hours at $4^{\circ} \mathrm{C}$. The fixed cells were washed in three changes of PBS buffer for 10 minutes each, and post fixed in $1 \%$ osmium tetroxide for 2 hours at $4^{\circ} \mathrm{C}$. The samples were then washed in three changes of PBS buffer ( $\mathrm{pH}$ 7.4) for 10 minutes each, dehydrated in ascending grades of ethanol (35\%, 50\%, 75\%, 95\%, and 100\%), and dried in air for 2 hours. The specimens were viewed using a Phenom G2 pro desktop scanning electron microscope at an accelerating voltage of $10 \mathrm{kV}$.

\section{Cell growth curve}

The AMJ13 cell line was cultured in 30 mini Petri dishes ( $3 \mathrm{~mL}$ ). The cells were counted using a Neubauer hemtocytometer at 24-hour intervals for 10 days at early passages of continuous cell culture. The population doubling time was determined using the following formula:

\section{Doubling time $($ hours $)=0.693(\mathrm{t}-\mathrm{t} 0) / \ln (\mathrm{Nt} / \mathrm{N} 0)$}
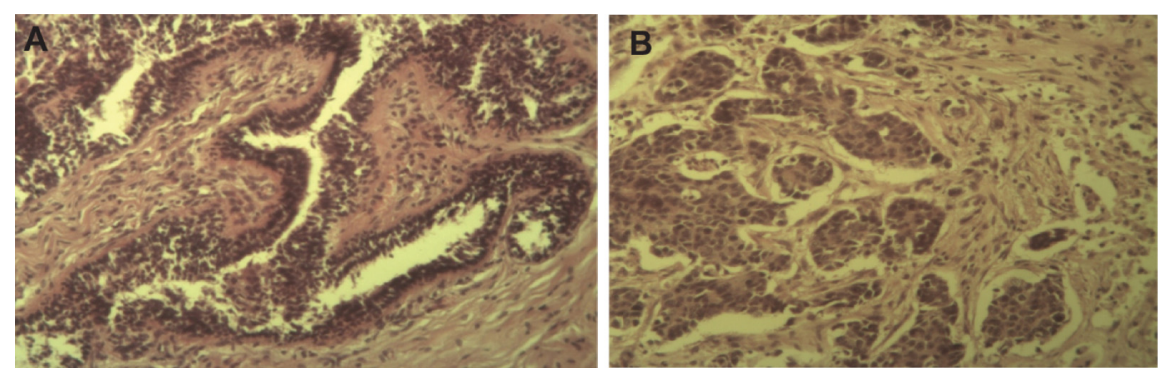

Figure I Histopathological sections of the original tumor of which the AMJ I 3 cell line was derived from.

Notes: (A) A duct containing finger-like projections covered by a layer of epithelial and underlying myoepithelial cells with a fibrous core (hematoxylin and eosin staining, magnification 40×). (B) Infiltrating ductal carcinoma composed of irregular solid groups of cells in a dense fibrous stroma (hematoxylin and eosin staining, magnification $40 \times$ ). 
where $\mathrm{t}$ is the time in hours, $\mathrm{t} 0$ is the time at which exponential growth occurs, Nt is the cell number at time t, and N0 is the cell number at t0. ${ }^{11}$

\section{Anchorage-independent growth assay}

The AMJ13 cells were detached from the flask by trypsinization. Next, 10,000 cells were prepared as single cell suspensions in $0.35 \%$ agar with $1 \mathrm{~mL}$ of culture medium, and seeded onto $1 \mathrm{~mL}$ of hard agar (1\% prepared in culture medium) in a 12 -well plate. The cells were then incubated at $37^{\circ} \mathrm{C}$ in a humidified $5 \% \mathrm{CO}_{2}$ incubator for 41 days. The cell colonies were then fixed for observation, and images were taken using an inverted microscope. Colony diameters were quantified using the image analysis software MICROVISIBLE. The protocol was performed according to Voisin et $\mathrm{al}^{12}$ with modifications.

\section{Analysis of karyotype}

The AMJ13 cells were karyotyped at passages 39 and 40. We used the protocol described by Yassen ${ }^{13}$ as modified by the cytogenetics laboratory at the Iraqi Center for Cancer and Medical Genetic Research. Briefly, confluent AMJ13 cell monolayers were treated with colcemid (Kreatech Biotechnology) for 1 hour and then dispersed with $0.5 \%$ trypsin. The harvested cells were washed in physiological solution, treated with $0.075 \mathrm{M} \mathrm{KCl}$ solution for 40 minutes at $37^{\circ} \mathrm{C}$, and then fixed in a mixture of glacial acetic acid and methanol $(1: 6, \mathrm{v} / \mathrm{v})$. The cell suspension was dropped onto a glass slide and stained with Giemsa dye to examine the slide and in preparation for chromosome $\mathrm{G}$ banding.

\section{Immunocytochemistry}

AMJ13 cells were cultured to a confluent monolayer on Labtek chamber slides, then fixed in 4\% formalin for 10 minutes, rinsed gently in PBS, and incubated in a humid chamber, first with blocking reagents for 1 hour and then with selected primary antibodies, ie, mouse anti human-Her neu2, mouse anti human-PR, mouse anti human-ER BRCA1 and BRAC2, and vimentin (Santa Cruz Biotechnology), overnight at $4^{\circ} \mathrm{C}$ for detection of markers for breast cancer. The antibodies were diluted (1:50-100) according to the manufacturer's recommendations. We used the standard protocol for the biotin-streptavidin staining kit (Santa Cruz Biotechnology).

\section{Results}

\section{Establishment of primary cell culture}

Several primary cultures were initiated using samples from Iraqi breast cancer patients, but only one sample (the AMJ13 cell line) could be successfully cultured. The first passage from the primary culture was done after 16 days, with subcultures repeated continuously for at least 2 years (March 2013 through April 2015) and the cells were subcultured every 3-4 days.

\section{Morphology and morphometry of cultured cells}

The cultured AMJ13 cells had an elongated multipolar epithelial-like cell shape, with nuclear polymorphism and multiple nuclei in most of the cells, as well as showing many cells
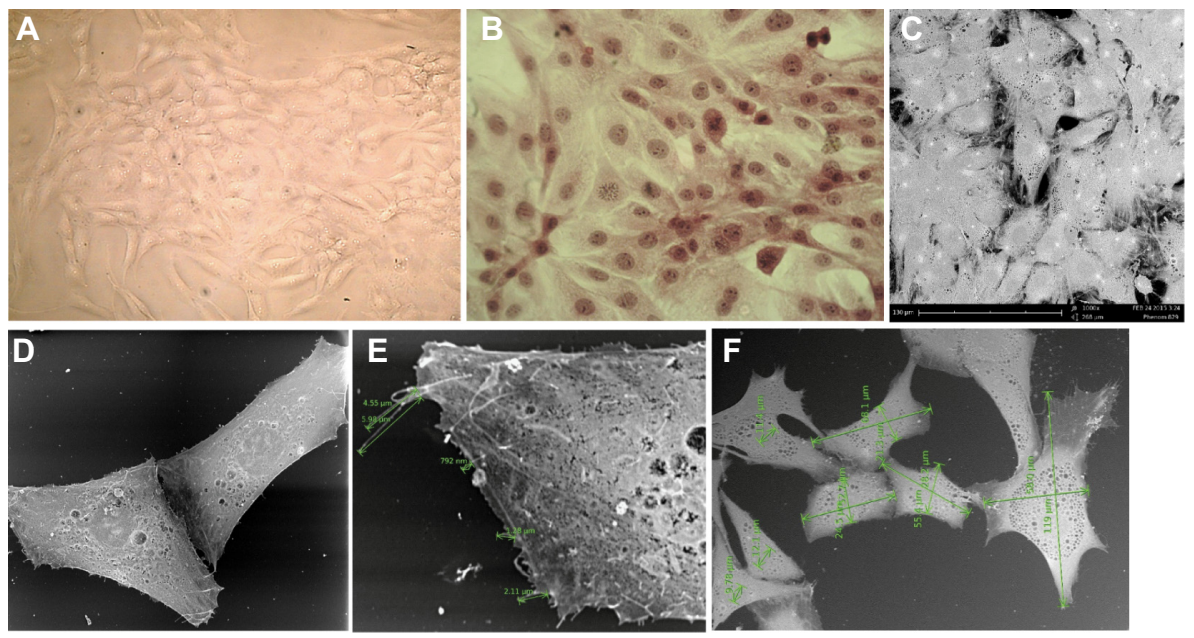

Figure 2 AMJ 13 cell line morphology.

Notes: (A) Morphology of AMJI3 cells in culture showing (B) an epithelial-like cell shape with multiple nuclei, a high N/C ratio, and the presence of mitotic figures (hematoxylin and eosin staining, magnification 40X). (C) Scanning electron micrographs of human breast cancer-derived cell cultures. The cells are squamous with many short and thin processes and grow upon each other (magnification I,000X). (D) Scanning electron photomicrograph showing AMJI3 cells with characteristic epithelial polygonal shape (magnification 3,000×) (E) Scanning electron photomicrograph showing microvilli on the cancer cells that ranged from $0.792 \mu \mathrm{m}$ to $5.98 \mu \mathrm{m}$ in length (magnification $10,000 \times)$. (F) Scanning electron photomicrograph showing the measurements for AMJI3 cancer cells, for which the average length was $73.8 \mu \mathrm{m}$, the average width was $33 \mu \mathrm{m}$, and the average nucleus diameter was II.I $\mu \mathrm{m}$ (magnification I,000×). 
with mitotic figures, which expressed the characteristics of cell morphology (Figure 2A and B). Figure 2D is a scanning electron photomicrograph showing AMJ13 cells with a characteristic polygonal epithelial squamous shape with many short and thin processes, with cells growing upon each other. Measurements taken by scanning electron microscopy indicated a mean cell length of $73.8 \mu \mathrm{m}$, a mean cell width of $33 \mu \mathrm{m}$, and a mean nucleus diameter of $11.1 \mu \mathrm{m}$. Microvilli were also present, and ranged from $0.792 \mu \mathrm{m}$ to $5.98 \mu \mathrm{m}$ in length (Figure 2E).

\section{Growth curve and doubling time}

The growth kinetics of the AMJ13 breast cancer cell line were studied at passage 10, and the cell growth curve is shown in Figure 3. The population doubling time was calculated to be 22 hours.

\section{Anchorage-independent growth assay}

We evaluated the ability of these cells to grow in an anchorage-independent fashion using soft agar colony assays. The cells readily formed colonies ( $>50 \mu \mathrm{m}$ diameter) within 6 days (Figure 4A), with a mean diameter of $93.85 \mu \mathrm{m}$. After 14 days, the colonies were continuing to expand, reaching a mean diameter of $282.75 \mu \mathrm{m}$ (Figure 4B).

\section{Analysis of karyotype}

Cytogenetic analysis of the AMJ13 cell line showed a complex karyotype with many abnormal structural and numerical changes, with the main chromosomal aberrations resulting from rearrangement, breaks, and translocations (Figure 4). The $\mathrm{G}$ banding of the chromosomes of the passage 39 cells

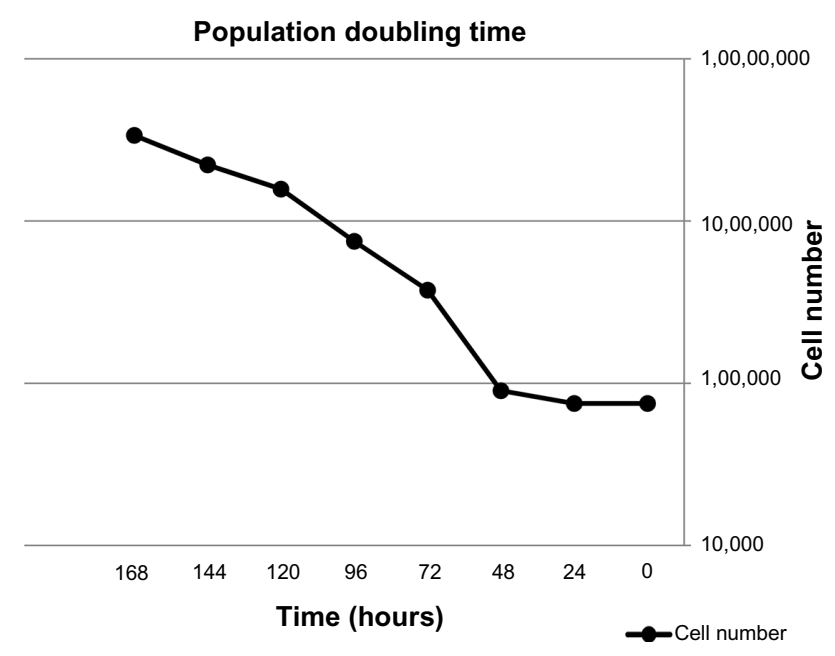

Figure 3 Growth curve for AMJI3 cell line, with a population doubling time of 22 hours. used to estimate the karyotyping of the new established breast cancer cell line, because it has the most dominant clones which were examined.

The chromosomal aberrations of the new established breast cancer cell line were both numerical and structural. Chromosomal numbers differed between the cells (Figure 5) that ranged from 31 to 45 were $44 \%$, this represented the majority of cells in the population on the slide, second group that revealed $31 \%$ percentage of cells with chromosome number $(<30)$ and $25 \%$ been cells with chromosome number more than 47 (Figure 6 and 7).

\section{Immunocytochemistry}

ER, PR, and Her-neu2 gene expression in the AMJ13 breast cancer cell line was detected using an anti-mouse IgG immunocytochemistry kit (Figure 8A-C). The results showed that the cells were negative for ER and PR, and weakly positive for Her-neu2 gene expression when compared with a negative control. Rabbit anti-mouse BRCA1 and BRCA2 genes and vimentin were used to detect these important markers. AMJ13 cells were positive for BRCA1 nuclear staining, but to a lesser degree than BRCA2, which was positive for both nuclear and cytoplasmic staining (Figure 8D and E). Vimentin was strongly positive (Figure $8 \mathrm{~F}$ ).

\section{Discussion}

Here we describe the development and characterization of the first continuous breast cancer cell line from an Iraqi patient, known as the AMJ13 cell line. There are presently more than 70 breast cancer cell lines in the American Type Culture Collection, but few of them are derived from Asians. ${ }^{4}$ The AMJ13 cell line is the first Arabian and Middle Eastern breast cancer cell line and was derived from an Iraqi patient with histologically diagnosed poorly differentiated infiltrative ductal carcinoma. It was graded $3 / 3$ according to the Nottingham modification of the Bloom-Richardson system and T2, N0, Mx on TNM staging. Cell lines from primary breast carcinoma are among the most difficult to establish in culture. ${ }^{14}$

Established human cancer cell lines are a valuable resource for studying cancer cell biology, and these cultured cells are considered to be a model for the physiological processes occurring in vivo and for developing new strategies to combat cancer cell growth and progression of the disease. ${ }^{4}$ Cell cultures established directly from human tumors serve as unique models for studying and manipulating potentially relevant molecular and cellular processes underlying malignant disease and identification of novel biological therapeutic 

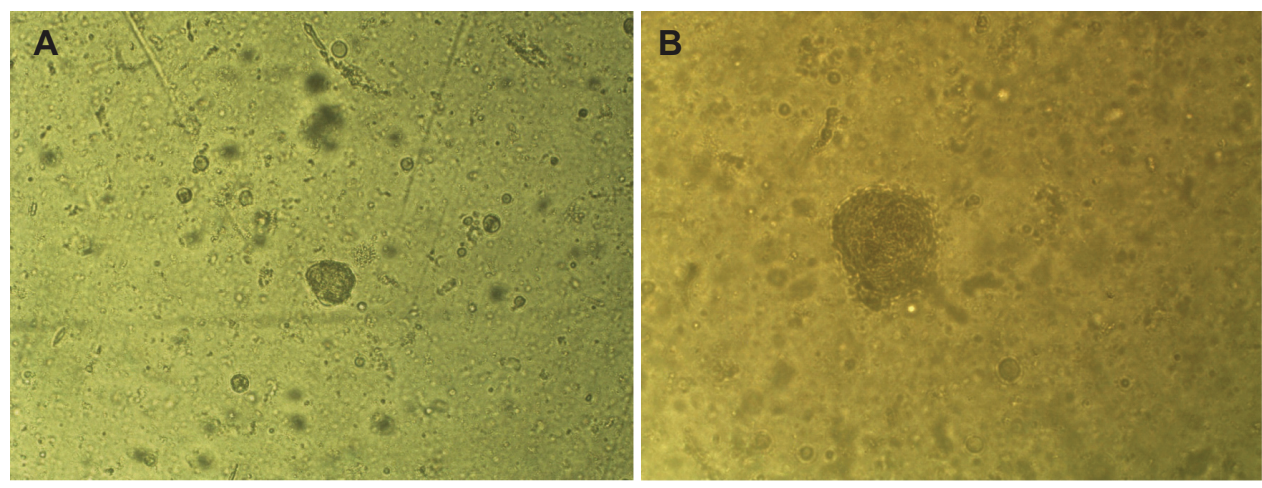

Figure 4 AMJ 13 cells growing in an anchorage-independent fashion using soft agar colony assays.

Notes: (A) AMJI 3 cells readily formed colonies (93.85 $\mu \mathrm{m}$ in diameter) within 6 days. (B) After 14 days, the colonies continue to expand, reaching $282.75 \mu \mathrm{m}$ in mean diameter. This result demonstrates that AMJI3 cells undergo efficient anchorage-independent growth.

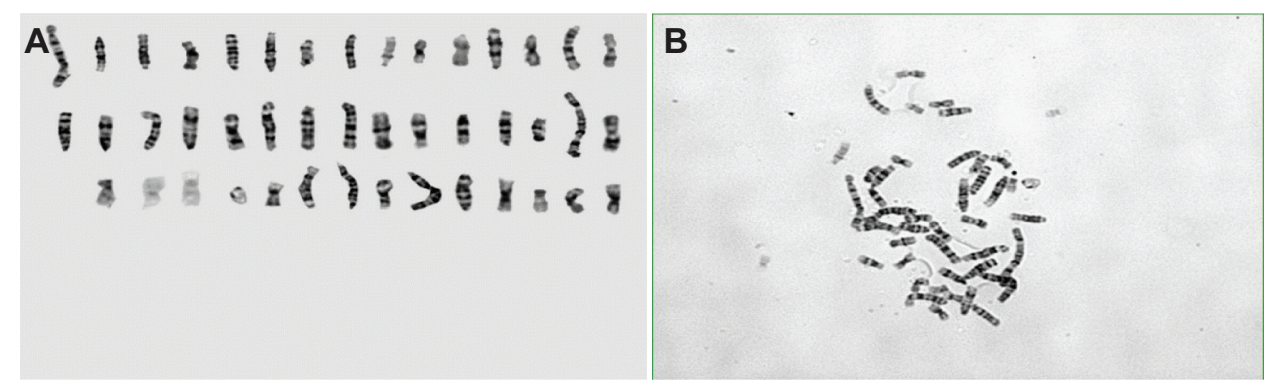

Figure 5 Analysis of Karyotype.

Notes: (A) Representative metaphases. (B) G band karyotype for the established breast cancer cell line that show most chromosomes as markers.

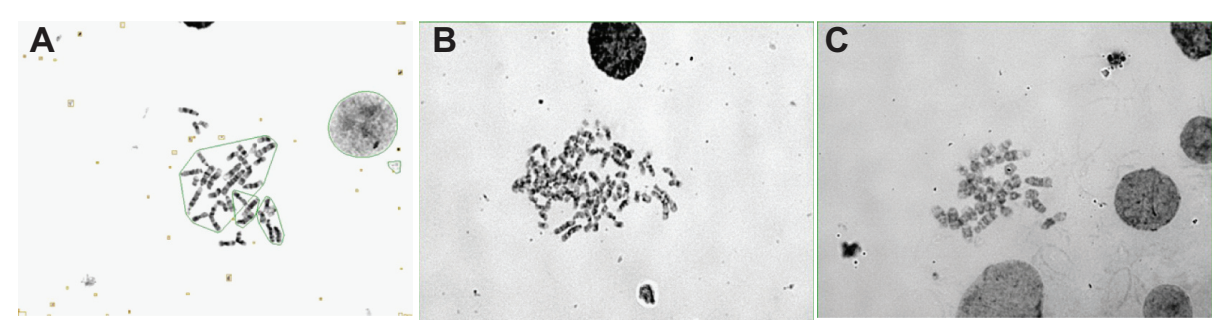

Figure 6 Chromosome numbers differ between cells.

Notes: (A) disrupted metaphase with 33 chromosome, (B) disrupted metaphase with chromosome number more than 47, and (C) disrupted metaphase with chromosome number less than 30 .

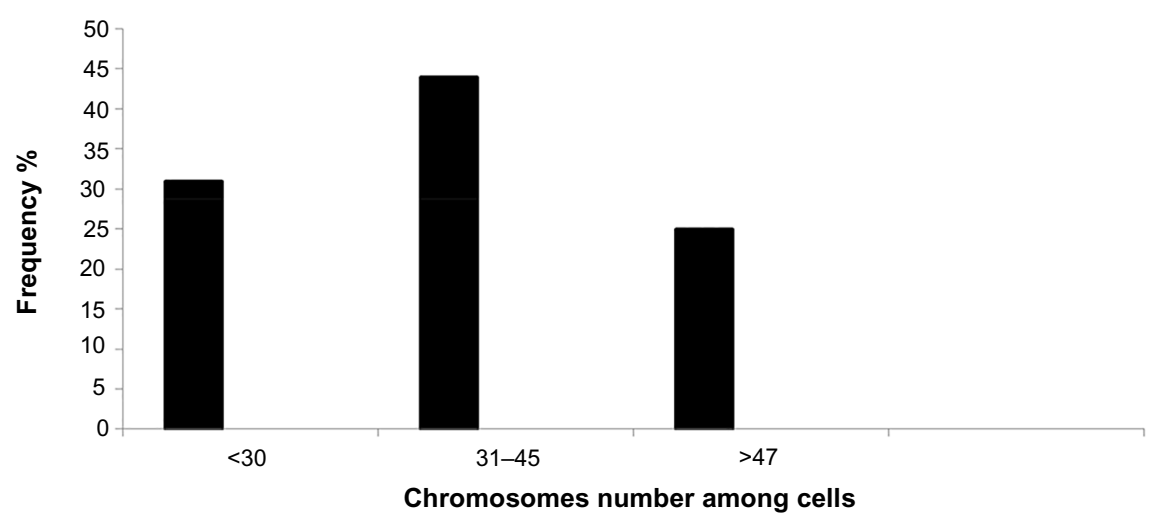

Figure 7 Histogram showing abnormal chromosome numbers in AMJI3 cells. 

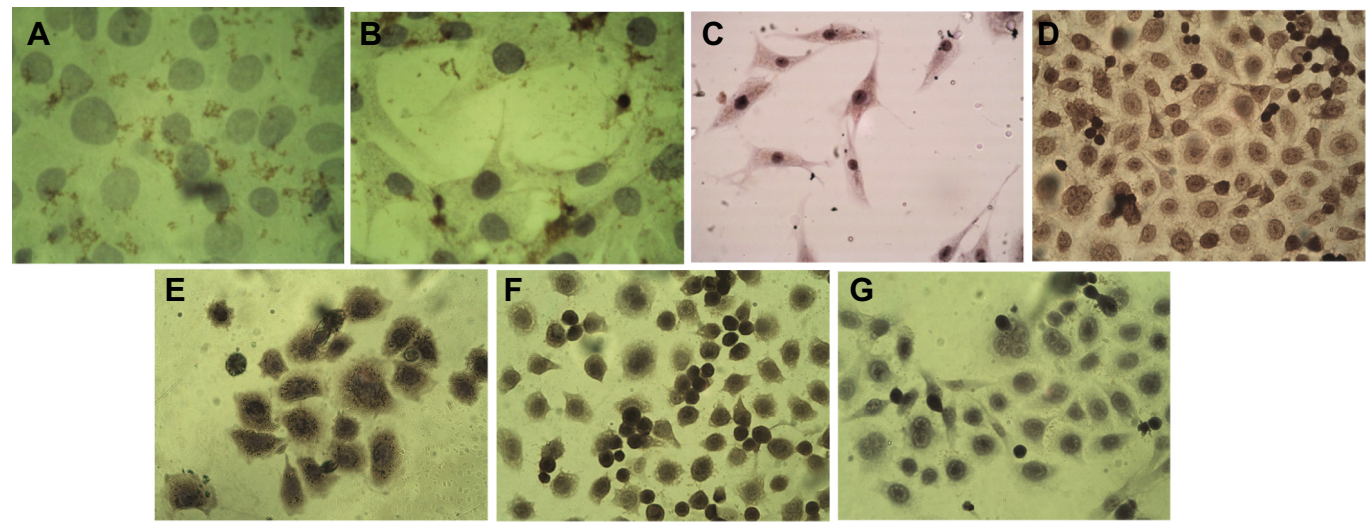

Figure 8 Immunocytochemistry analysis of AMJI 3 cell line.

Notes: (A) Negative result for ER (magnification 40X). (B) Negative result for PR (magnification 40X). (C) Weak positive result for Her-neu2 gene expression (magnification 40×). (D) BRCAI-positive nuclear staining of breast cancer epithelial cells (magnification 40X). (E) BRCA2-positive nuclear and cytoplasmic staining of breast cancer cells (magnification 40×). (F) Vimentin marker-positive cells (magnification 40×). (G) Negative control.

targets. The majority of breast cancer-derived cell lines are derived from secondary tumors or pleural effusions in patients with advanced breast cancer. ${ }^{3}$

The newly established AMJ13 cell line grew as an adherent monolayer with characteristic elongated epithelial-like cell morphology. Scanning electron microscopy confirmed that these cells having a characteristic polygonal epithelial squamous shape with many short and thin processes, and that they grow upon each other, confirming loss of contact inhibition, which is one of the features of transformation. The cultured cells maintained a morphology consistent with that of the primary culture in subsequent subculture passages, as occurs in other breast cancer cell lines with the same morphological characteristics. ${ }^{4}$

Measurements taken by scanning electron microscopy showed that these cancer cells had a mean length of $73.8 \mu \mathrm{m}$, a mean width of $33 \mu \mathrm{m}$, a mean nucleus diameter of $11.1 \mu \mathrm{m}$, and microvilli ranging from $0.792 \mu \mathrm{m}$ to $5.98 \mu \mathrm{m}$ in length. These measurements will be useful for future studies attempting to characterize these cells after a long time in culture. Cytoplasmic protrusions and morphological features similar to those in our AMJ13 cells have been demonstrated in other cell lines, including those for human breast cancer epithelial cells. ${ }^{15}$

Our cells have been grown continuously for over 2 years and have undergone more than 70 passages. The AMJ13 cell line appears to be immortal, given that growth has continued after recovery from cryopreservation.

The AMJ13 cell population doubling time is 22 hours, which is more rapid than for many other breast cancer cell lines. The BC-021 cell line, established from invasive ductal carcinoma in Chinese patients, has a doubling time of 46 hours, ${ }^{4}$ as does the HMA-1 cell line. ${ }^{16}$ However, the population doubling time of our AMJ13 cell line is similar to the 28 hours noted for the ANGM5 cell line established from an Iraqi patient with cerebral glioblastoma. ${ }^{17}$ The similarity in population doubling time between our new established cell line and that of the ANGM5 cell line, as well as the difference to other non-Iraqi cell line may be refer to external conditions such as environmental or ethnic factors specific to Iraq. Some researchers have reported that environmental risk factors affected the nature of cancers. ${ }^{18} \mathrm{AMJ} 13$ cells have the ability to grow in an anchorage-independent fashion in soft agar colony assays, with formation of colonies within 6 days and continued expansion at 14 days, which confirms the transformed nature of these cells and their potential for metastasis. ${ }^{19}$

Analysis of the AMJ13 cell karyotype showed abnormal numerical and structural changes in the chromosomes, indicating a complex karyotype resulting from chromosomal rearrangement, breaks, and translocation. These complex aberrations showing chromosomes with abnormal undefined structure that we call it "marker chromosomes". Marker chromosomes are characterized by their abnormal length and structure in comparison with normal human chromosomes, which can lead to a decrease in the number of chromosomes in the cells to less than 46 .

The appearance of marker chromosomes is common in cancer cells, and results from irregular cell cycle division. This phenomenon was reported by Matano et al, ${ }^{16}$ who identified four marker chromosomes among 41 chromosomes in the karyotype of an HMA-1 breast cancer cell line. Further, Wang et $\mathrm{al}^{20}$ identified 20 marker chromosomes in the karyotype of a HDQ-P1 breast cancer cell line. Similar chromosomal aberrations have been reported in the Iraqi ANGM5 glioblastoma cell line, ${ }^{17}$ which shows marker chromosomes but no normal 
chromosomes within the cell. ${ }^{21}$ The chromosomal instability in general cause aneuploidy cells to be harmful more than the effect from change in nucleotide level, this chromosomal instability effects on wide range of proliferation, apoptosis and differentiation of normal cells converted to tumor cells by loss the function of suppressor gene or loss the inhibition of oncogene or both effectors. All these factors may generate tumor cells that are resistant to antitumor agents. ${ }^{22}$

The immunocytochemistry analysis showed that most of the AMJ13 cells weakly expressed the HERneu2 protein, with no PR or ER expression. ER, PR, and HER-neu2 gene expression status influences the management of breast cancer $^{23}$ because it provides both therapeutic and prognostic information ${ }^{24}$ and predicts the response to endocrine therapy. ${ }^{25}$ AMJ13 cells were positive for BRCA1 nuclear staining, but to a lesser degree than for BRCA2, which was positive for both nuclear and cytoplasmic staining. Tulchin et $\mathrm{al}^{26}$ frequently found reduced BRCA1 nuclear staining in breast tumor tissue when compared with normal tissue, and less BRCA1 staining with higher histological tumor grade. Strong positive staining of the nucleus and cytoplasm suggests mutation in $B R C A 1$ because of its role in cell cycle control and DNA repair. BRCA2 mutation causes multiple chromosomal abnormalities, as shown in the cytogenetic analysis reported by Gretarsdottir et al, ${ }^{27}$ which was consistent with the complex chromosomal abnormalities found in our AMJ13 cell line. Moreover, our AMJ13 breast cancer cell line is strongly positive for vimentin, and Vora et $\mathrm{al}^{28}$ have reported that gain of vimentin expression is an indicator of biologically aggressive breast carcinoma.

\section{Conclusion}

We have successfully established an Iraqi breast cancer cell line, which to our knowledge is the first in the Middle East, and is named AMJ13 (for the research team and patients' initials and the year in which the line was established). The AMJ13 cell line has a very complex and interesting karyotype with many numerical and structural abnormalities as well as loss of expression of two important receptors (ER and PR), weak Her/neu2 protein expression, and positivity for BRCA1/2 and vimentin. This cell line will be a very helpful tool in breast cancer research and could assist in developing new therapies for this disease.

\section{Acknowledgment}

This work was supported by the Iraqi Center for Cancer and Medical Genetic Research, Mustansiriya University, the Iraqi Ministry of Higher Education and Scientific Research.

\section{Disclosure}

The authors report no conflicts of interest in this work.

\section{References}

1. Coleman MP, Quaresma M, Berrino F, et al. Cancer survival in five continents: a worldwide population-based study (CONCORD). Lancet Oncol. 2008;9(8):730-756.

2. Iraqi Cancer Board. Results of the Iraqi Cancer Registry 2009. Baghdad, Iraqi Cancer Registry Center, Ministry of Health. 2010

3. Pandrangi SL, Raju Bagadi SA, Sinha NK, et al. Establishment and characterization of two primary breast cancer cell lines from young Indian breast cancer patients: mutation analysis. Cancer Cell Int. 2014; 14(1): 14 .

4. Shen C, Gu M, Liang D, et al. Establishment and characterisation of three new human breast cancer cell line derived from Chinese breast cancer tissues. Cancer Cell Int. 2009;9:2.

5. Brenton JD, Carey LA, Ahmed AA, Caldas C. Molecular classification and molecular forecasting of breast cancer: ready for clinical application? J Clin Oncol. 2005;23(29):7350-7360.

6. Aström AK, Jin D, Imamura T, et al. Chromosomal localization of three human genes encoding bone morphogenetic protein receptors. Mamm Genome. 1999;10(3):299-302.

7. Trent JM. Cytogenetic and molecular biologic alterations in human breast cancer: a review. Breast Cancer Res Treat. 1985;5(3):221-229.

8. Gebhart E, Brüderlein S, Augustus M, Siebert E, Feldner J, Schmidt W. Cytogenetic studies on human breast carcinomas. Breast Cancer Res Treat. 1986;8(2):125-138.

9. Cervenka J, Koulischer L. In: Gorlin R, editor. Chromosomes in Human Cancer. Springfield, IL, USA: Charles C Thomas; 1973.

10. Gioanni J, Le François D, Zanghellini E, et al. Establishment and characterisation of a new tumorigenic cell line with a normal karyotype derived from a human breast adenocarcinoma. Br J Cancer. 1990;62(1): $8-13$.

11. Doyle A, Griffiths B. Cell and Tissue Culture for Medical Research. New York, NY, USA: Wiley Interscience; 2000.

12. Voisin L, Julien C, Duhamel S, et al. MEK2 is sufficient but not necessary for proliferation and anchorage-independent growth of SK-MEL-28 melanoma cells. PLoS One. 2008;8:337.

13. Yaseen N. Cytogenetic study of human colorectal cancer cell. PhD thesis. Sheffield, UK: University of Sheffield; 2000.

14. Heo CK, Bahk YY, Cho EW. Tumor-associated autoantibodies as diagnostic and prognostic biomarkers. BMB Rep. 2012;45(12):677-685.

15. Hass R, Bertram C. Characterization of human breast cancer epithelial cells (HBCEC) derived from long term cultured biopsies. J Exp Clin Cancer Res. 2009;28:127.

16. Matano S, Ohuchi N, Hirakawa H, et al. Establishment of an estrogen receptor-positive cell line (HMA-1) derived from human breast carcinoma. Tohoku J Exp Med. 1991;164(2):169-182.

17. Al-Shammari AM, Al-Juboory A, Asmaa A, Ali AM, Al-Hili ZA, Yaseen NY. Establishment and characterization of a chemoresistant glioblastoma cell line from an Iraqi patient. Abstract presented at the 105th Annual Meeting of the American Association for Cancer Research, April 5-9, 2014, San Diego, CA, USA.

18. King JB, Robins MW. Cancer Biology. 2nd ed. Upper Saddle River, NJ, USA: Pearson Prentice Hall Inc.; 2000.

19. Mori S, Chang JT, Andrechek ER, et al. Anchorage-independent cell growth identifies tumors with metastatic potential. Oncogene. 2009;28(31):2796-2805.

20. Wang CS, Goulet F, Lavoie J, et al. Establishment and characterization of a new cell line derived from a human primary breast carcinoma. Cancer Genet Cytogenet. 2000;120(1):58-72. 
21. Almukhtar AA. Studying chromosomal aberration and some gene abnormalities in local glioblastoma cell line. MSc thesis. Baghdad, Iraq: Council of Science for Women, University of Baghdad.

22. Tresnasari K, Takakuwa T, Ham MF, Rahadiani N, Nakajima H, Aozasa K. Telomere dysfunction and inactivation of the P16(INK4a)/Rb pathway in pyothorax-associated lymphoma. Cancer Sci. 2007;98(7):978-984.

23. Azizun-Nisa, Bhurgri Y, Raza F, Kayani N. Comparison of ER, PR and HER-2/neu (C-erb B 2) reactivity pattern with histologic grade, tumor size and lymph node status in breast cancer. Asian Pac J Cancer Prev. 2008;9(4):553-556.

24. Onitilo AA, Engel JM, Greenlee RT, Mukesh BN. Breast cancer subtypes based on ER/PR and Her2 expression: comparison of clinicopathologic features and survival. Clin Med Res. 2009;7:4-13.
25. Cui X, Schiff R, Arpino G, Osborne CK, Lee AV. Biology of progesterone receptor loss in breast cancer and its implications for endocrine therapy. J Clin Oncol. 2005;23(30):7721-7735.

26. Tulchin N, Ornstein L, Dikman S, et al. Localization of BRCA1 protein in breast cancer tissue and cell lines with mutations. Cancer Cell Int. 2013;13(1):70.

27. Gretarsdottir S, Thorlacius S, Valgardsdottir R, et al. BRCA2 and p53 mutations in primary breast cancer in relation to genetic instability. Cancer Res. 1998;58(5):859-862.

28. Vora HH, Patel NA, Rajvik KN, et al. Cytokeratin and vimentin expression in breast cancer. Int J Biol Markers. 2009;24(1):38-46.

\section{Publish your work in this journal}

Breast Cancer: Targets and Therapy is an international, peerreviewed open access journal focusing on breast cancer research, identification of therapeutic targets and the optimal use of preventative and integrated treatment interventions to achieve improved outcomes, enhanced survival and quality of life for the cancer patient.
View the full aims and scopes of this journal here. The manuscript management system is completely online and includes a very quick and fair peer-review system, which is all easy to use. Visit http:// www.dovepress.com/testimonials.php to read real quotes from published authors.

Submit your manuscript here: http://www.dovepress.com/breast-cancer---targets-and-therapy-journal 